\title{
Posterior Cranial Fossa Meningioma Causing Tonsillar Herniation and Giant Cervicothoracic Syringomyelia, Case Report and Review of Literature
}

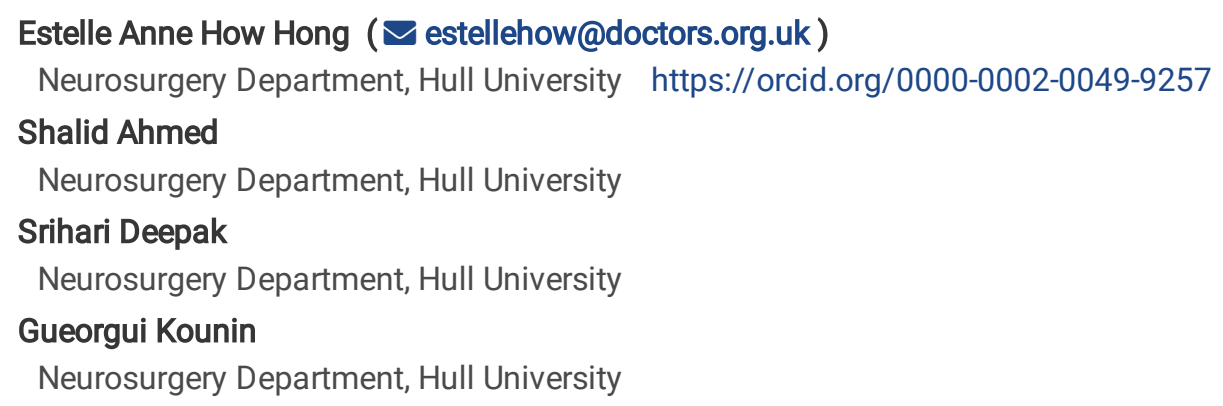




\section{Abstract \\ Background}

Syringomyelia is a fluid-filled cyst within the spinal cord and usually associated with Arnold-Chiari malformation. Posterior cranial fossa tumours are a rare cause of tonsillar herniation and secondary syringomyelia.

\section{Case Presentation:}

We report a rare case of a 56-year-old female with posterior cranial meningioma and secondary syringomyelia, admitted with headache, nausea, vomiting, and ataxic gait. MRI demonstrated a large posterior fossa lesion causing early ventriculomegaly and syrinx within the upper spinal cord extending from the hindbrain inferiorly to the level of T8. She underwent a posterior fossa craniectomy with left $\mathrm{C} 1$ hemilaminectomy and complete excision of the tumour. In 6 months following her procedure, MRI scan showed a significant reduction in the calibre of the syringomyelia throughout its length and there was a significant improvement in symptoms.

\section{Literature review:}

A PubMed literature search was carried out with keywords: "syringomyelia", "posterior fossa" and "tumour". 120 articles were reviewed. The inclusion criteria for this study was posterior fossa meningioma causing syrinx formation. A total of 9 isolated similar cases were identified.

\section{Discussion}

Tonsillar herniation and syringomyelia secondary to posterior cranial fossa meningioma are rare. The alteration in the dynamic flow of CSF is likely to be the cause for the formation and enlargement of the syrinx.

\section{Conclusion}

Although the pathophysiology of syrinx formation is still poorly understood, the alteration of CSF dynamic has been implicated, but a common unifying cause appears to be increased transcranial difference in intracranial pressure across the foramen magnum causing tonsillar herniation, irrespective of location in the posterior fossa. Posterior fossa craniotomy and excision of the lesion is the mainstay treatment.

\section{Introduction}

Syringomyelia is a poly-etiologic disorder characterized by a fluid-filled cyst within the spinal cord. It is associated with conditions that obstruct the CSF (cerebrospinal fluid) flow at the foramen magnum or spinal levels such as Chiari malformations, arachnoiditis, and basilar invaginations ${ }^{[1]}$. Posterior fossa tumours are a rare cause of secondary syringomyelia. We present a rare case of a 55 -year-old lady with a large posterior fossa fibrous meningioma causing secondary syringomyelia extending to T8 and early ventriculomegaly. To the best of our knowledge, there have been only 9 reported cases in English language literature in which most syringomyelia extended to the cervicothoracic region and our case report being the most extensive syringomyelia reported. We carried out a literature review to discuss the disease course, common pathogenesis, and its management.

\section{Case Report}

56-year-old female, right-handed dominant with a background of hypertension, presents with a 2-year history of constant frontal headaches, severe nausea, and vomiting, and a significant weight loss of 4 stone over 12 months. Furthermore, she had a year of mild weakness of the voice as well as gross ataxic gait and poor coordination.

She underwent an MRI scan of the head and the whole spine which demonstrated a large posterior fossa lesion measuring $3.6 \mathrm{~cm}$ to the left of the midline which was compressing the cerebellum, see figure 1 and partially effacing the fourth ventricle and right-sided tonsillar herniation extending $7 \mathrm{~mm}$ below the foramen magnum, see figure 2. There was associated narrowing of the left foramen of Luschka 
and the foramen of Magendie, associated with ventriculomegaly and a syrinx within the upper cord, which extends from the hindbrain inferiorly to the level of T8, see figure 3(a-c). She was commenced on dexamethasone and a proton pump inhibitor and after multidisciplinary team discussion, she was scheduled for surgery.

\section{Procedure}

She underwent a posterior fossa craniectomy with $\mathrm{C} 1$ hemilaminectomy and Simpson 1 excision of the lesion. She was positioned into a Park-bench lateral position with the left side up and her head was in Mayfield pins. A left question mark/hockey stick incision was made curving back towards midline over C1 / C2 and extending over the midline to the right side. Dissection was done to expose bone until foramen magnum and arch of $\mathrm{C} 1$. C2 was palpable with some muscle stripping on left. The left mastoid process was palpable just at the edge of exposure.

A craniectomy was using two burrholes and craniotome and this was extended to the superior border up to inion. A small durotomy at the superior edge was used as starting point to open the dura. The dura excised around the tumour and there was significantly dilated occipital and circular sinus with venous oozing and therefore ties and ligaclips were used around the occipital sinus for haemostasis. There was a wide attachment base along cerebellar falx and dura towards the foramen magnum requiring a wider opening of the latter with a left partial $\mathrm{C} 1$ hemilaminectomy. Internal debulking of tumour was performed using the ultrasonic aspirator and subsequently, the bulk of the tumour was removed by excision along with the dural attachment.

A small further attachment of the tumour along the midline occipital sinus was removed using coagulation and microscissors. There were some adhesions between the tonsils until the obex and inferior portion of the 4th ventricle, which were divided. The posterior inferior cerebellar artery was identified and preserved.

\section{Post-operative}

After the procedure, she was kept in the Intensive care unit post operatively, she had regular neurological observations and her blood pressure was kept normotensive. A CT scan of the head at 48 hours postoperatively showed complete removal of the posterior fossa meningioma with no evidence of enhancing residuum. Histology confirmed a fibrous meningioma WHO grade 1. She was then discharged back to her based hospital for more rehabilitation but unfortunately, she contracted COVID-19. However, she recovered fully and was discharged back home.

A follow-up MRI scan of the head and spine at 6 months postoperatively showed complete excision of the meningioma, no active hydrocephalus, see figure 4 and a significant reduction in the calibre of the syringomyelia along its entire length, see figure 5 . The patient reported significant improvement in the frequency of headaches and improvement in balance and coordination when compared to the preoperative state. Nausea and vomiting had completely resolved.

\section{Review of literature}

A PubMed literature search was carried out with keywords: "syringomyelia", "posterior fossa", and "tumour" and about 120 articles reviewed. The inclusion criteria for this study were posterior fossa meningiomas causing syrinx formation. Studies including other space-occupying lesion with no syrinx identified were excluded Articles not written in English were excluded.

\section{Results}

A total of nine isolated similar cases were identified. See Table 1 
Table 1

showing summary of the reported cases of Posterior cranial fossa meningioma causing syringomyelia within the current literature

\begin{tabular}{|c|c|c|c|c|c|c|c|c|}
\hline Author & Age/Sex & $\begin{array}{l}\text { Location of } \\
\text { tumour }\end{array}$ & $\begin{array}{l}\text { Primary } \\
\text { symptoms }\end{array}$ & $\begin{array}{l}\text { Duration } \\
\text { of } \\
\text { symptoms }\end{array}$ & $\begin{array}{l}\text { Tonsillar } \\
\text { herniation }\end{array}$ & $\begin{array}{l}\text { Syrinx } \\
\text { level and } \\
\text { extent }\end{array}$ & Surgery & $\begin{array}{l}\text { Syrinx } \\
\text { Follow up }\end{array}$ \\
\hline \multirow[t]{2}{*}{ Tachibana $^{[1]}$} & $\begin{array}{l}\text { 53/ } \\
\text { Female }\end{array}$ & $\begin{array}{l}\text { Tentorium } \\
\text { cerebelli }\end{array}$ & $\begin{array}{l}\text { Increased } \\
\text { ICP, } \\
\text { cerebellar } \\
\text { signs, none } \\
\text { with } \\
\text { sensory } \\
\text { disturbance } \\
\text { to syrinx } \\
\text { formations }\end{array}$ & 3 years & present & $\mathrm{C} 2$ & N/A & Reduction \\
\hline & $\begin{array}{l}\text { 50/ } \\
\text { Female }\end{array}$ & $\begin{array}{l}\text { Adjacent to the } \\
\text { pyramis }\end{array}$ & $\begin{array}{l}\text { Symptoms } \\
\text { of raised } \\
\text { ICP, } \\
\text { involvement } \\
\text { of the 7th, } \\
\text { 8th cranial } \\
\text { nerves and } \\
\text { cerebellar } \\
\text { signs }\end{array}$ & 2 years & present & $\mathrm{C} 1$ & $\mathrm{~N} / \mathrm{A}$ & N/A \\
\hline $\begin{array}{l}\text { Bouras } \\
2006^{[2]}\end{array}$ & $\begin{array}{l}\text { 55/ } \\
\text { Female }\end{array}$ & $\begin{array}{l}\text { right sighted } \\
\text { extra-axial } \\
\text { infratentorial } \\
\text { tumour } \\
\text { measuring } 4 \times 4 \\
\mathrm{~cm}\end{array}$ & $\begin{array}{l}\text { Progressive } \\
\text { numbness } \\
\text { and } \\
\text { dysesthesia }\end{array}$ & 6 years & present & C1-C4 & $\begin{array}{l}\text { Suboccipital } \\
\text { craniectomy }\end{array}$ & $\begin{array}{l}\text { Reduction } \\
\text { in } 1 \text { year }\end{array}$ \\
\hline $\begin{array}{l}\text { Bhatoe } \\
2004^{[3]}\end{array}$ & $\begin{array}{l}\text { 38/ } \\
\text { Female }\end{array}$ & $\begin{array}{l}\text { Extra-axial } \\
\text { contrast- } \\
\text { enhancing } \\
\text { meningioma } \\
\text { arising from } \\
\text { tentorium on the } \\
\text { right side and } \\
\text { compressing } \\
\text { the cerebellum. }\end{array}$ & $\begin{array}{l}\text { Generalized } \\
\text { headache, } \\
\text { vomiting, } \\
\text { unsteady } \\
\text { gait and } \\
\text { increased } \\
\text { ICP }\end{array}$ & 6 months & present & $\mathrm{C} 2$ & $\begin{array}{l}\text { Retro- } \\
\text { mastoid } \\
\text { Craniectomy }\end{array}$ & $\begin{array}{l}\text { Reduction } \\
\text { in } 3 \\
\text { months }\end{array}$ \\
\hline Fox $^{[4]}$ & $\begin{array}{l}\text { 53/ } \\
\text { Female }\end{array}$ & $\begin{array}{l}4 \times 4.5 \mathrm{~cm} \text {, extra- } \\
\text { axial, } \\
\text { homogenously } \\
\text { enhancing } \\
\text { tumor that } \\
\text { appeared to } \\
\text { originate from } \\
\text { the right petrous } \\
\text { dura } \\
\text { compressing } \\
\text { and displacing } \\
\text { the lateral } \\
\text { recess of the } \\
\text { fourth ventricle } \\
\text { to the left }\end{array}$ & $\begin{array}{l}\text { Occipital } \\
\text { pain, } \\
\text { nystagmus, } \\
\text { hypesthesia } \\
\text { in the right } \\
\text { C2 } \\
\text { dermatome }\end{array}$ & 6 months & present & C2-C6 & $\begin{array}{l}\text { Retro- } \\
\text { mastoid } \\
\text { Craniectomy }\end{array}$ & $\begin{array}{l}\text { Reduction } \\
\text { in } 1 \text { year }\end{array}$ \\
\hline Karttunen ${ }^{[5]}$ & $\begin{array}{l}\text { 34/ } \\
\text { Female }\end{array}$ & tentorial & $\begin{array}{l}\text { Nausea, } \\
\text { vertigo, } \\
\text { cerebellar } \\
\text { ataxia, left- } \\
\text { sided hemi } \\
\text { syndrome }\end{array}$ & 3 weeks & present & C2-T2 & $\begin{array}{l}\text { Suboccipital } \\
\text { craniectomy }\end{array}$ & $\begin{array}{l}\text { Reduction } \\
\text { in } 22 \\
\text { months }\end{array}$ \\
\hline Jaiswal[ $^{[6]}$ & $\begin{array}{l}\text { 30/ } \\
\text { Female }\end{array}$ & $\begin{array}{l}\text { right } \\
\text { cerebellopontine } \\
\text { angle extra-axial } \\
\text { tumour }\end{array}$ & $\begin{array}{l}\text { Headache, } \\
\text { gait ataxia, } \\
\text { muscle } \\
\text { wasting }\end{array}$ & 5 years & present & $\begin{array}{l}\text { Cervico- } \\
\text { medullary } \\
\text { junction } \\
\text { to C3 }\end{array}$ & $\begin{array}{l}\text { retromastoid } \\
\text { suboccipital } \\
\text { craniectomy }\end{array}$ & $\mathrm{N} / \mathrm{A}$ \\
\hline
\end{tabular}




\begin{tabular}{|c|c|c|c|c|c|c|c|c|}
\hline Author & Age/Sex & $\begin{array}{l}\text { Location of } \\
\text { tumour }\end{array}$ & $\begin{array}{l}\text { Primary } \\
\text { symptoms }\end{array}$ & $\begin{array}{l}\text { Duration } \\
\text { of } \\
\text { symptoms }\end{array}$ & $\begin{array}{l}\text { Tonsillar } \\
\text { herniation }\end{array}$ & $\begin{array}{l}\text { Syrinx } \\
\text { level and } \\
\text { extent }\end{array}$ & Surgery & $\begin{array}{l}\text { Syrinx } \\
\text { Follow up }\end{array}$ \\
\hline $\begin{array}{l}\text { Del } \\
\text { Maestro[7] }\end{array}$ & $\begin{array}{l}17 / \\
\text { Female }\end{array}$ & $\begin{array}{l}\text { left sighted } \\
\text { extra-axial } \\
\text { tumor in the } \\
\text { PCF, originating } \\
\text { from the } \\
\text { petrous bone, } \\
\text { measuring } \\
6 \times 5 \times 6.5 \mathrm{~cm}\end{array}$ & $\begin{array}{l}\text { Dizziness, } \\
\text { paresthesia, } \\
\text { headache, } \\
\text { neck pain, } \\
\text { loss of } \\
\text { balance } \\
\text { dysesthesia } \\
\text { in upper } \\
\text { limb, left } \\
\text { hearing } \\
\text { loss, } \\
\text { nystagmus }\end{array}$ & 1 month & present & $\begin{array}{l}\text { Medulla } \\
\text { oblongata } \\
\text { to C7 }\end{array}$ & $\begin{array}{l}\text { Retrosigmoid } \\
\text { craniectomy }\end{array}$ & $\begin{array}{l}\text { Resolution } \\
\text { of syrinx } \\
\text { at } 6 \\
\text { months }\end{array}$ \\
\hline Kankane $^{[8]}$ & $\begin{array}{l}35 / \\
\text { Female }\end{array}$ & Left tentorium & $\begin{array}{l}\text { Sub- } \\
\text { occipital } \\
\text { headache, } \\
\text { vertigo, gait } \\
\text { difficulties } \\
\text { and } \\
\text { nystagmus }\end{array}$ & 3 years & present & $\begin{array}{l}\text { Cervico- } \\
\text { medullary } \\
\text { junction } \\
\text { to C4 }\end{array}$ & $\begin{array}{l}\text { Suboccipital } \\
\text { craniectomy }\end{array}$ & $\begin{array}{l}\text { Resolution } \\
\text { of syrinx } \\
\text { in } 6 \\
\text { months }\end{array}$ \\
\hline
\end{tabular}

\section{Discussion}

\section{Pathogenesis}

Tonsillar herniation and syringomyelia secondary to posterior cranial fossa meningiomas are rare entity, described as 'external syringomyelia' ${ }^{[9]}$. Although the pathophysiological mechanism of syrinx formation secondary to posterior cranial fossa lesion is not yet clear, it implied that the mass effect of the posterior cranial lesion leads to tonsillar herniation which amounts to syringomyelia, an entity recently described by authors as an Acquired Chiari malformation (ACM) ${ }^{[3,10]}$. Unlike primary Chiari Malformation (CM), in which syringomyelia is present in $30-70 \%$ of cases, the presence of syringomyelia in ACM was found to be $82 \%{ }^{[10]}$. In addition, there is thought to be underdevelopment of the posterior fossa dimensions in a primary $\mathrm{CM}$, which is not the case with secondary tonsillar herniation.

The obstruction of CSF flow at the foramen magnum may lead to an increased pulse pressure within the spinal canal that may force the entry of CSF into the spinal cord ${ }^{[1,3,11]}$. In our literature review, all cases of posterior fossa meningioma with syringomyelia had tonsillar herniation noted on the initial scan, further supporting this association. It is however difficult to distinguish if whether the posterior fossa tumour causes secondary tonsillar herniation and subsequent syringomyelia or the growth of a posterior fossa tumour predisposes to a worsening of a coexistent Chari Malformation.

A hypothesis to explain this elucidates that with the presence of obstruction of CSF at the foramen magnum, various activities such as coughing, straining, assuming an erect position or pulsatile fluctuations of CSF pressure during the cardiac cycle leads to a transient increase in CSF pressure above the blockage. This leads to corresponding changes in transmural venous and capillary pressure resulting in vasodilatation below the block and collapse of vessels above the blockage. These uneven changes in vessel diameter cause mechanical stress on the spinal cord, especially more caudal to the level of blockage. This combined with dilatation of vessels finally disrupts the blood-spinal cord barrier, allowing ultrafiltration of crystalloids and accumulation of a protein-poor fluid. Over time, extensive gliosis, oedema, and vascular wall thickening will occur ${ }^{[12]}$.

\section{Presentation}

Headache appears to be the most common feature in the presenting complaint as reported in six of the studies in the literature review $[3,4,6-8]$. The most common examination finding was ataxic gait ${ }^{[1,2,5,6,8]}$. It is however difficult to differentiate whether the symptoms are caused by cerebellar compression, associated hydrocephalus, or syrinx. The presence of secondary tonsillar herniation and the associated syringomyelia can potentially cause symptoms both independent of and in addition to those caused by the tumour. Tumour size or biology does not appear to show any direct correlation with syrinx size ${ }^{[11]}$. The proximity of the tumour to the CSF pathway can also determine the clinical presentation. 
Surgical resection was performed in all nine cases reviewed in the literature. Three cases underwent retromastoid craniectomies ${ }^{[3,4,7]}$ with three others undergoing suboccipital craniectomies ${ }^{[2,5,8]}$. A systematic review of ACM and syringomyelia secondary to spaceoccupying lesions showed that in all but one case the syringomyelia improved or disappeared completely with surgical resection of the underlying lesion without any patients requiring a subsequent syrinx shunt ${ }^{[10]}$. Most patients reported improvement in symptoms after surgical resection of the tumour with five cases showing complete resolution of preoperative symptoms ${ }^{[2,3,6-8]}$. Two of the cases showed some residual mild weakness in the peripheries ${ }^{[1]}$.

In our case report, there was a significant reduction in the diameter of the syringomyelia along its entire length 6 months after treatment. Goel et al reported in a study of cases with longstanding benign tumour at the foramen magnum were found to have significantly higher mean spinal canal diameter at both the $\mathrm{C} 6$ and $\mathrm{T} 2$ spinal levels than in controls ${ }^{[9]}$. Additionally, there was a marginal reduction even in the extent of syringomyelia (which extends from the C2 to the mid T7 level, compared to the previous lower border of T8) in our case report. This is the most extensively reported secondary syringomyelia compared to our literature review. We concur with Levine et al that increased difference in CSF pressure, with the turbulence of flow across the foramen magnum worsened by tonsillar herniation, is strongly associated with the possibility of syrinx formation ${ }^{[12]}$. Furthermore, with high syrinx pressure, mechanical stress-induced structural change of the spinal cord occurs, allowing the persistence and progression of the syrinx in the spinal cord which can be quite extensive as in our case. Regardless, as the patient's symptoms have significantly improved 6 months after her operation, we note that significant clinical improvement precedes radiological resolution of syringomyelia.

\section{Conclusion}

Posterior cranial fossa meningioma causing tonsillar herniation and secondary syringomyelia extending to the thoracic cord is rare. The exact pathophysiology of syrinx formation is still not completely understood but is likely related to the alteration of CSF flow dynamic, especially with daily activities and/or progression in the course of the lesion. It is important to distinguish this from a primary CM where there is thought to be underdevelopment of posterior fossa dimensions. Posterior fossa craniectomy/craniotomy and resection of the lesion facilitate a reduction in tonsillar herniation and thus preventing their descent and subsequent blockage of CSF at the foramen magnum. The re-establishment of CSF flow allows the resolution of hydrocephalus and syrinx with very few cases needing subsequent CSF diversion of the syrinx.

\section{Abbreviations}

- Acquired Chiari malformation (ACM)

- Chiari Malformation (CM)

- CSF (cerebrospinal fluid)

\section{Declarations}

\section{Ethics approval and consent to participate}

Not Applicable

\section{Consent for publication}

Authors confirm that the patient involved in case study described in the paper has given written consent to the inclusion of material pertaining to herself, that she has acknowledged that she cannot be identified via the paper; and that we have fully anonymized them.

\section{Availability of data and materials}

Not Applicable

\section{Competing interests}

The authors declare that they have no competing interests 


\section{Funding}

The author declares that there is no specific grant from any funding agency in the public, commercial, or not-for-profit sectors

\section{Authors' contributions}

$\mathrm{EHH}$ analysed the patient's data, performed the literature review and discussion and was a major contributor in writing the manuscript. SA collected and analysed the patient data. SD and GK reviewed the manuscript and provided feedback. All authors read and approved the final manuscript.

\section{Acknowledgements}

Not Applicable

\section{References}

1. Tachibana S, Harada K, Abe T, Yamada H, Yokota A. Syringomyelia secondary to tonsillar herniation caused by posterior fossa tumors. Surgical Neurology. 1995;43(5):471-7.

2. Bouras $\mathrm{TI}$, Kouyialis AT, Boviatsis EJ, Sakas DE. Symptomatic syringomyelia secondary to clinically obscure infratentorial tumour. Br J Neurosurg. 2006;20(1):48-50.

3. Bhatoe HS. Tonsillar herniation and syringomyelia secondary to a posterior fossa tumour. Br J Neurosurg. 2004;18(1):70-1.

4. Fox B, Muzumdar D, DeMonte F. Resolution of tonsillar herniation and cervical syringomyelia following resection of a large petrous meningioma: case report and review of literature. Skull Base. 2005;15(1):89-98.

5. Karttunen A, Heikkinen E, Tuominen J, Jartti P. Secondary Syringomyelia Disappearing after Removal of Tentorial Meningioma. Acta Neurochirurgica. 2002;144(7):741-2.

6. Jaiswal AK, Chandra PS. Cerebellopontine angle meningioma with acquired chiari and syringomyelia: neuroimage. Neurol India. 2001;49(3):323.

7. Del Maestro M, De Paulis D, Ricci A, Di Cola F, Galzio R. Syringobulbia associated with posterior fossa meningioma: a review of the literature. Childs Nerv Syst. 2014;30(10):1749-52.

8. Kankane VK, Jaiswal G, Gupta T. Large tentorium meningioma causing chiari malformation type-1 with syringomalia with complete resolution of syrinx and chiari after surgical excision: rare case report with review of literature. Romanian Neurosurgery. 2016;30:127 - 31 .

9. Goel A, Shah AH, Vutha R. External syringomyelia in longstanding benign foramen magnum tumors. Surg Neurol Int. 2020;11:92.

10. Wang J, Alotaibi NM, Samuel N, Ibrahim GM, Fallah A, Cusimano MD. Acquired Chiari Malformation and Syringomyelia Secondary to Space-Occupying Lesions: A Systematic Review. World Neurosurg. 2017;98:800-8.e2.

11. Galarza M, Lopez-Guerrero AL, Martinez-Lage JF. Posterior fossa arachnoid cysts and cerebellar tonsillar descent: short review. Neurosurg Rev. 2010;33(3):305-14; discussion 14.

12. Levine DN. The pathogenesis of syringomyelia associated with lesions at the foramen magnum: a critical review of existing theories and proposal of a new hypothesis. J Neurol Sci. 2004;220(1-2):3-21.

\section{Figures}




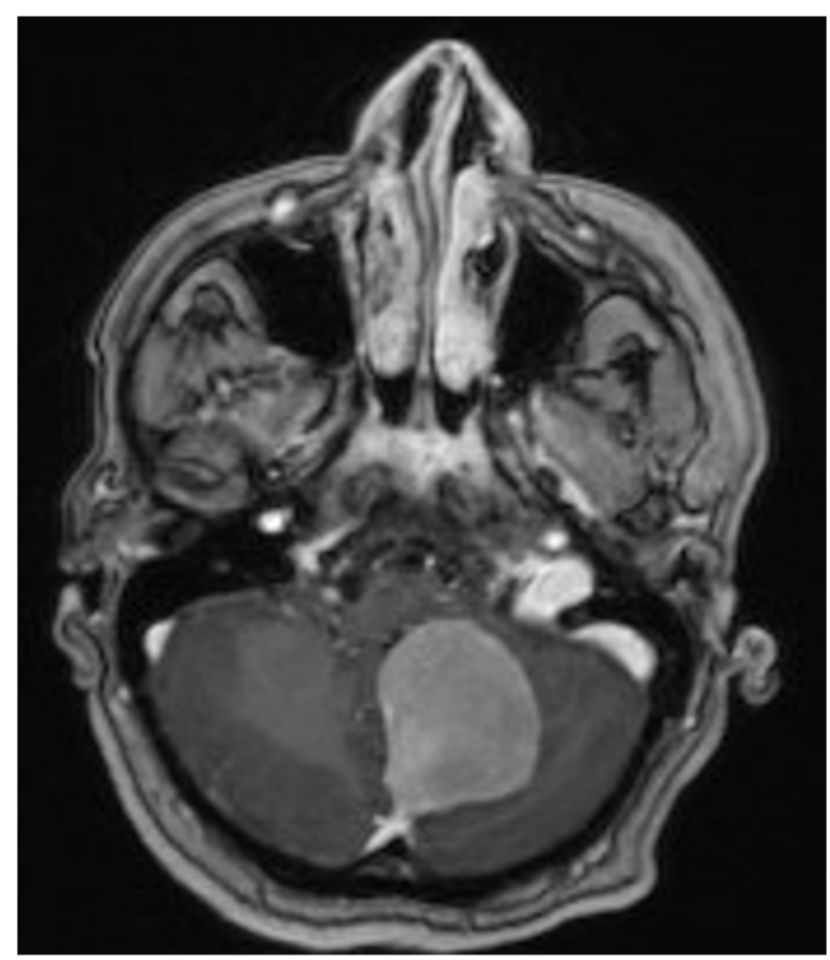

Figure 1

\section{Figure 1}

T1 axial weighted MRI with contrast demonstrating a left foramen magnum meningioma

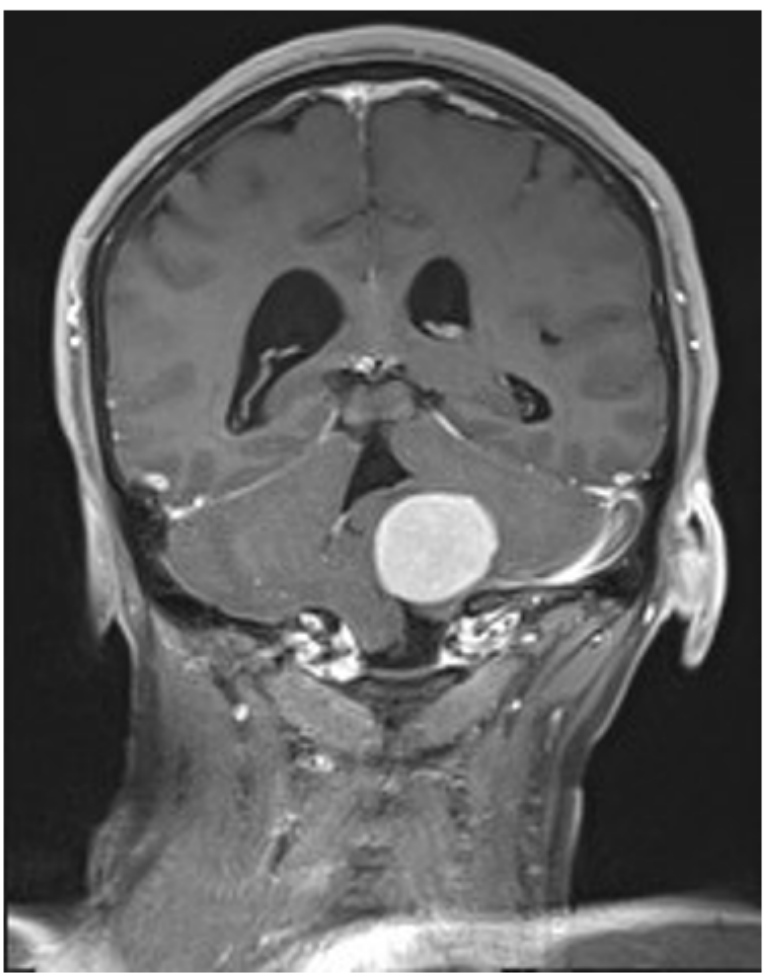

Figure 2

\section{Figure 2}

T1 coronal weighted MRI with contrast demonstrating right tonsillar herniation 


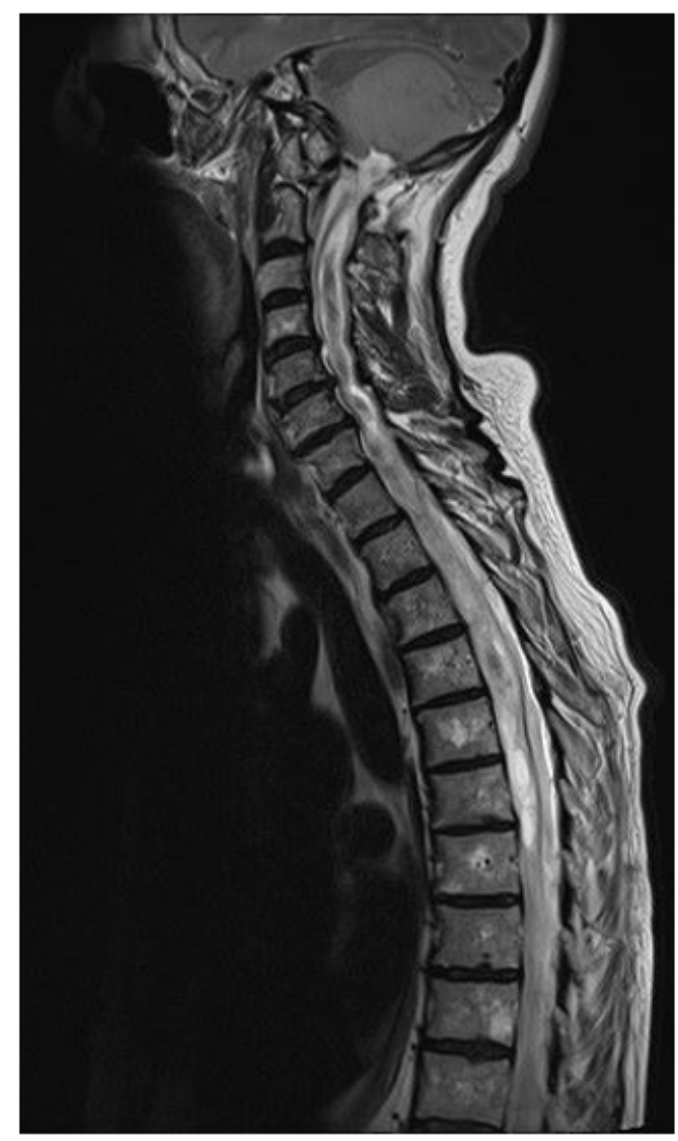

Figure 3

Figure 3

T2 sagittal MRI showing the extent of the cervicothoracic syrinx and the point of tonsillar narrowing at the foramen magnum just cranial to its origin. 


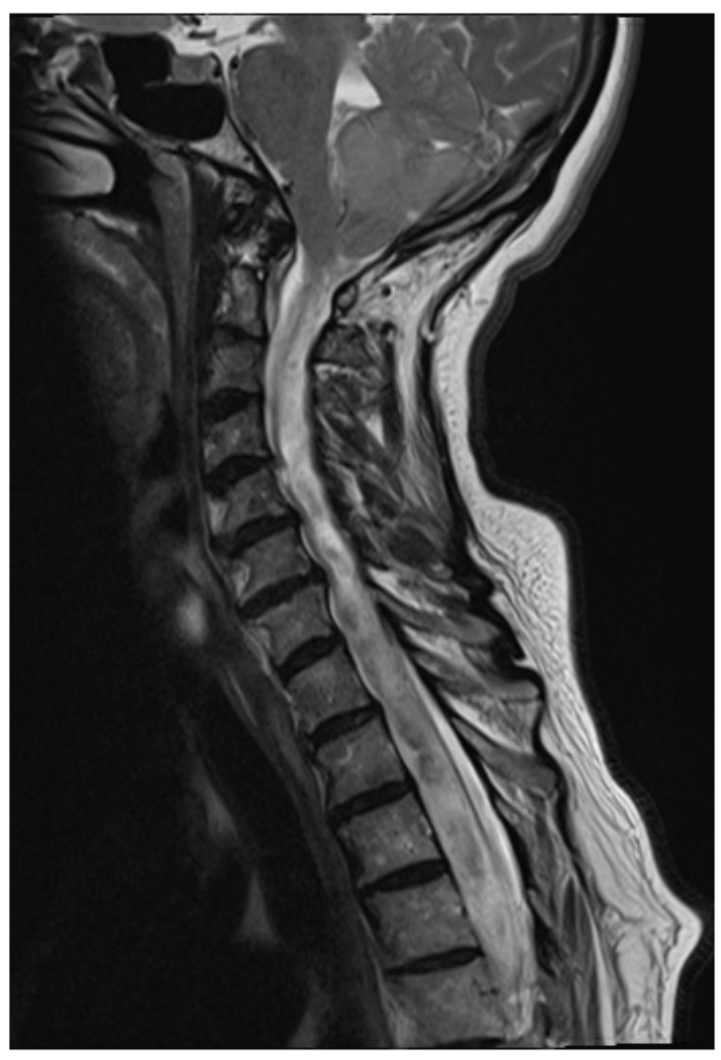

Figure 4

Figure 4

A follow-up MRI scan of the head and spine at 6 months postoperatively showed complete excision of the meningioma, no active hydrocephalus 


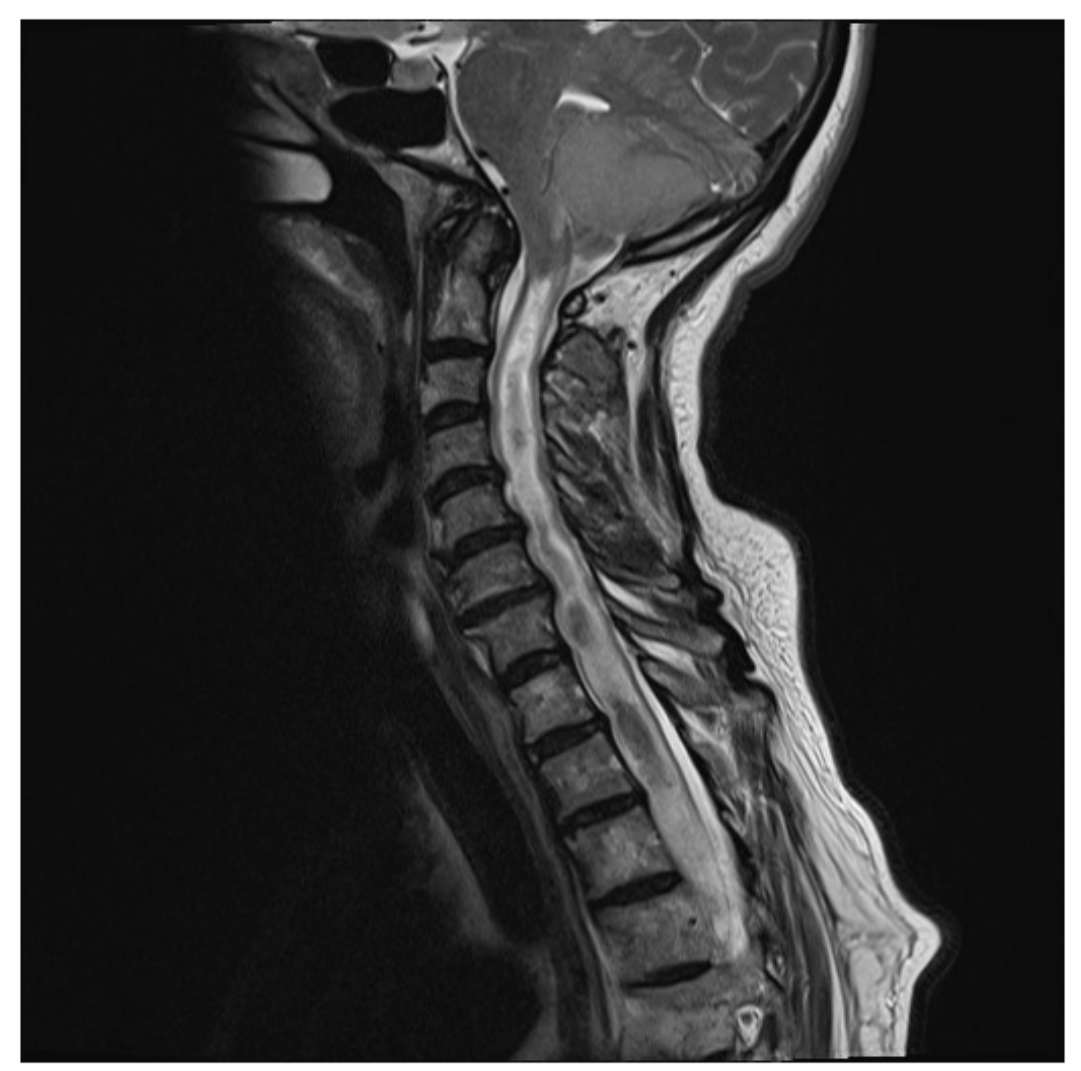

Figure 5

\section{Figure 5}

significant reduction in the calibre of the syringomyelia along its entire length 


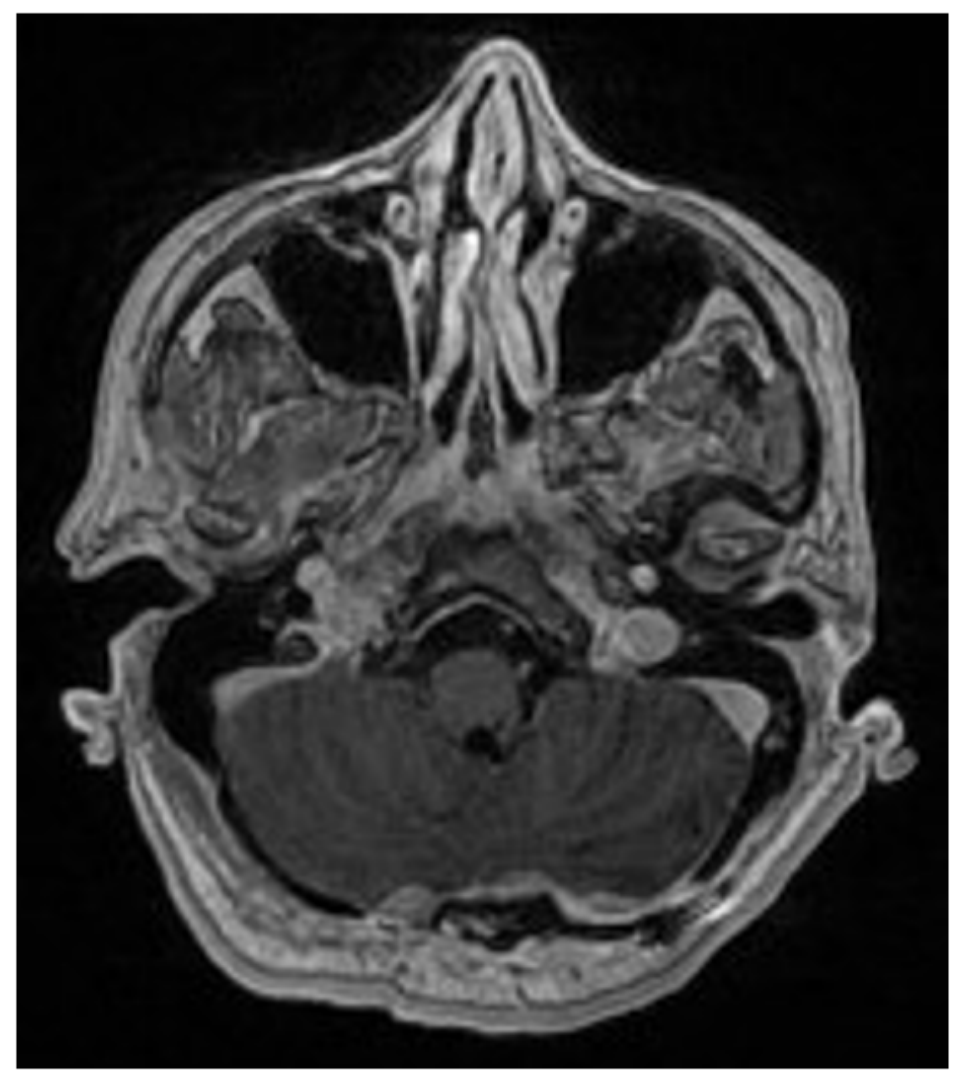

Figure 6

\section{Figure 6}

T1 axial weighted MRI showing complete resection of the meningioma. 


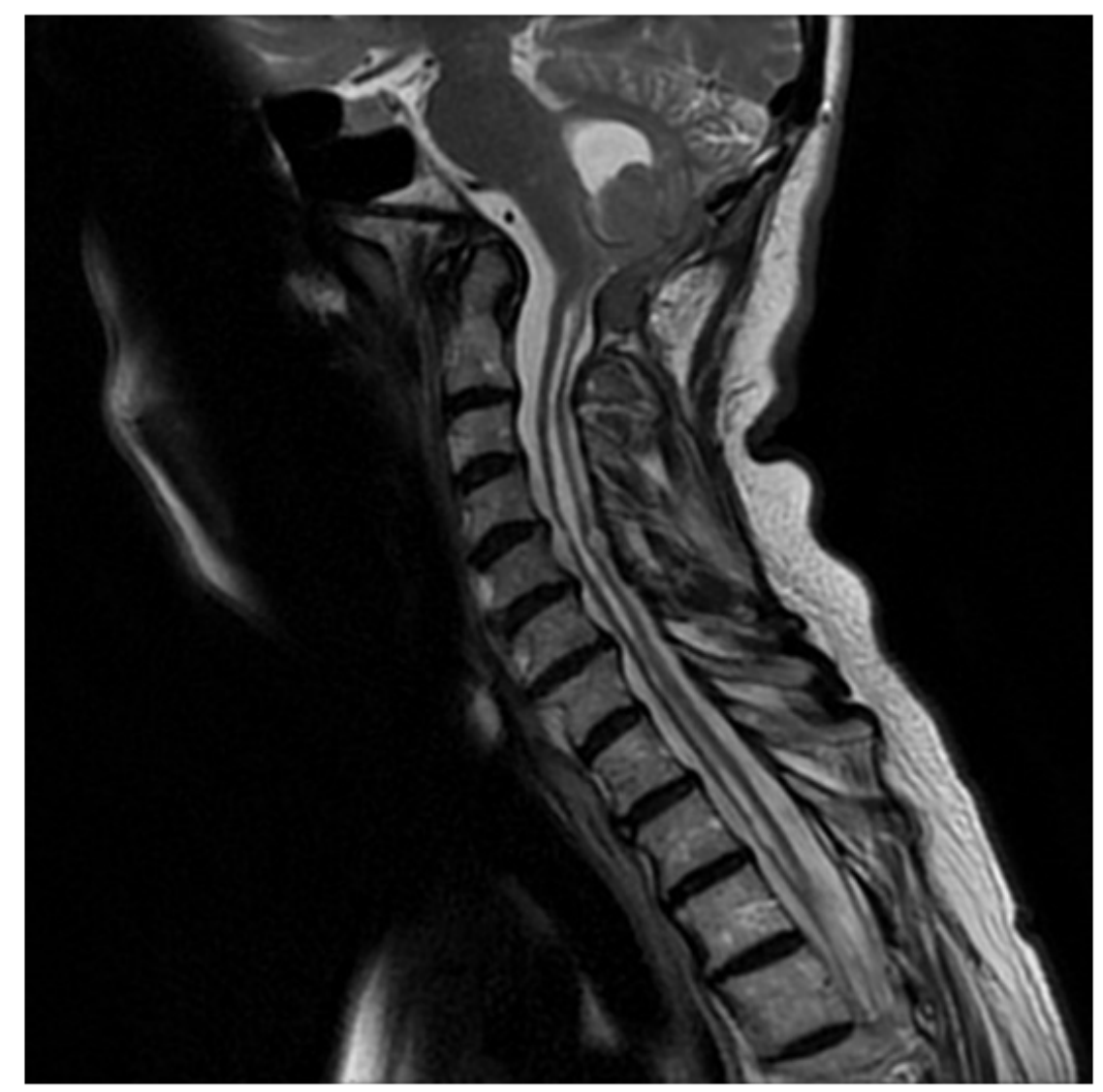

Figure 7

\section{Figure 7}

T2 sagittal MRI showing near-complete resolution of the syrinx throughout its length 